\title{
Does Prenatal Methamphetamine Exposure Induce Cross-sensitization to Cocaine and Morphine in Adult Male Rats?
}

\author{
Šlamberová R., Yamamotová A., Pometlová M., Schutová B., Hrubá L., \\ Nohejlová-Deykun K., Nová E., Macúchová E. \\ Department of Normal, Pathological and Clinical Physiology, Third Faculty of \\ Medicine, Charles University in Prague, Prague, Czech Republic \\ Received January 23, 2012; Accepted June 25, 2012.
}

Key words: Prenatal drug exposure - Methamphetamine - Cocaine - Morphine Open field - Plantar test - Conditioned place preference - Locomotion Nociception - Drug-seeking behavior

\begin{abstract}
The aim of the present study was to examine the cross-sensitization induced by prenatal methamphetamine (MA) exposure to challenge dose of cocaine or morphine. Rat mothers received a daily injection of MA $(5 \mathrm{mg} / \mathrm{kg})$ or saline throughout the gestation period. Adult male offspring (prenatally MA- or saline-exposed) were divided to groups with challenge doses of saline $(1 \mathrm{ml} / \mathrm{kg})$, cocaine $(5 \mathrm{mg} / \mathrm{kg})$ or morphine $(5 \mathrm{mg} / \mathrm{kg})$. Behavior in unknown environment was examined in Laboras, nociception in Plantar test, and active drug-seeking behavior in conditioned place preference (CPP). Our data demonstrate that cocaine increased the exploratory activity in Laboras test in prenatally saline-exposed, but decreased it in prenatally MA-exposed rats. An analgesic effect of cocaine was demonstrated only by the tail withdrawal and it was independent of the prenatal drug exposure. CPP test showed that prenatal MA exposure induced rather tolerance than sensitization to cocaine. In contrast to cocaine effects, morphine decreased rearing activity in both, prenatally MA-exposed and saline-exposed rats, and locomotion only in prenatally MA-exposed rats in the Laboras. In the Plantar
\end{abstract}

This study was supported by grant \# NS10509-3/2009 from Internal Agency of the Ministry of Health of the Czech Republic, grant \# 305/09/0126 from Grant Agency of the Czech Republic, project CSM 110 from Ministry of Education, Youth and Sports and project 264706/SVV/2012 from Charles University in Prague.

Mailing Address: Assoc. Prof. Romana Šlamberová, MD., PhD., Department of Normal, Pathological and Clinical Physiology, Third Faculty of Medicine, Charles University in Prague, Ke Karlovu 4, 12000 Prague 2, Czech Republic; Phone: + 420224902 713; Fax: + 420224902 750; e-mail: rslamber@If3.cuni.cz 
test, the results demonstrated that morphine had an analgesic effect in prenatally saline-exposed rats but this effect was suppressed in prenatally MA-exposed rats. In the CPP test morphine induced drug-seeking behavior, which however was not affected by prenatal drug exposure. Thus, our data demonstrate that there is a cross-effect between prenatal MA exposure and the challenge dose of other drug in adulthood, however drug-seeking behavior is not increased by prenatal MA exposure as we expected.

\section{Introduction}

Methamphetamine (MA) is one of the most common "hard" drugs abused by pregnant women (Marwick, 2000), which is also one of the most frequently used illicit drugs in the Czech Republic (Vavřínková et al., 2001). Since psychoactive drugs are able to cross blood-brain barrier (one of the most impervious barriers of the body), the placental barrier is even easier to go through. MA is a powerfully addictive psychostimulant that metabolizes slowly and its effect is long-lasting (8 to 24 h) (Marwick, 2000). This might be the reason that makes it so popular. The research of the long-term effects of prenatal MA exposure is not fully understood yet. Our laboratory specializes in investigation of the effects of drugs (especially $\mathrm{MA}$ ) on rat mothers and their progeny.

Our previous studies demonstrated that administration of MA during pregnancy attenuates maternal behavior of rat mothers (Šlamberová et al., 2005) and impairs postnatal development of their pups (Šlamberová et al., 2006). Further, we found that prenatal MA exposure with respect of adult MA challenge impairs the learning abilities tested in Morris water maze (Schutová et al., 2008), affects anxiety behavior (Schutová et al., 2009), alters pain sensitivity in Plantar tests in sex-specific manner (Yamamotová et al., 2011) and seizure susceptibility in adult male and female rats (Šlamberová et al., 2009; Bernášková et al., 2011). In our most recent studies we demonstrated that there is a sensitizing effect of prenatal MA exposure to the same drug in adulthood (Bubeníková-Valešová et al., 2009; Šlamberová et al., 2011a, b).

There are studies showing that abuse of one drug may increase sensitivity to another drug. This effect is called cross-sensitization (Bartoletti et al., 1985; He and Grasing, 2004; Valvassori et al., 2007). Cross-sensitization between amphetamine and cocaine was first demonstrated on changes of locomotor activity (Shuster et al., 1977; Bonate et al., 1997). Repeated pretreatment with amphetamine was shown to enhance the acquisition (Horger et al., 1992) and escalation of cocaine self-administration (Ferrario and Robinson, 2007). Microinjections of amphetamine into the ventral tegmental area were shown to increase cocaine self-administration under a progressive ratio procedure and to enhance reinstatement of cocaine seeking (Suto et al., 2002). Valvassori et al. (2007) found that rats chronically treated with methylphenidate showed augmented locomotor sensitization to D-amphetamine in the adolescent period. Other studies demonstrated that cross-sensitization may be induced not only between related drugs, such as cocaine and amphetamines 
(psychostimulants), but also between unrelated drugs, such as between opioids and cocaine (Leri et al., 2003; He and Grasing, 2004) or between endocannabinoids and cocaine (Arnold, 2005) or opioids (Fattore et al., 2005), respectively.

Furthermore, it was shown (Malanga and Kosofsky, 2003) that rodents exposed to various abused drugs in utero, became sensitized to the rewarding effects of drugs in adulthood. For example they responded to lower doses of drug than control animals. Increased predisposition of drug abuse in adulthood has been shown in prenatally cocaine-exposed (Heyser et al., 1992; Rocha et al., 2002; Estelles et al., 2006), cannabinoid-exposed (Vela et al., 1998) and morphineexposed offspring (Gagin et al., 1997) relatively to controls. They showed increased drug-seeking behavior in both "self-administration test" and "conditioned place preference test" (CPP). CPP is one of the most widespread drug reward tests (for review see Tzschentke, 1998). Based on Pavlovian conditioning principles, CPP reflects a preference for a context due to the contiguous association between the context and a drug-associated stimulus. It also presents important advantages, among which the possibility to reveal both reward and aversion, to test animals in a drug-free state and to allow simultaneous determination of locomotor activity (Fattore et al., 2005).

Thus, the above mentioned studies suggest that prenatal drug exposure may induce "cross-sensitization" in adulthood regardless to the type of a drug. This might suggest that prenatal drug exposure induces general predisposition to drug addiction in adulthood. To validate our hypothesis that prenatal drug exposure induces predisposition to drug abuse in general and may therefore induce cross-sensitization, two drugs were tested in adult prenatally MA-exposed male rats: (1) drug with similar mechanism of action (cocaine) that affects dopamine, serotonin and noradrenalin systems similar to MA, and (2) drug with different mechanism of action (morphine) that affects mostly opioid receptors. Tests examining drug reward, nociception and behavior changes induced by prenatal MA exposure were used for demonstration of cross-sensitization in adulthood.

\section{Methods}

All experimental procedures implemented in this report were reviewed and approved by the Institutional Animal Care and Use Committee and were in agreement with the Czech Government Requirements under the Policy of Humans Care of Laboratory Animals (No. 246/1992) and with the regulations of the Ministry of Agriculture of the Czech Republic (No. 311/1997).

Prenatal and postnatal animal care

Adult female Wistar rats (250-300 g) were delivered by Anlab (Prague, the Czech Republic) from Charles River Laboratories International, Inc. Animals were housed 4-5 per cage and left undisturbed for a week in a temperature-controlled $\left(22-24{ }^{\circ} \mathrm{C}\right)$ colony room with free access to food and water on a $12 \mathrm{~h}$ (light): 
$12 \mathrm{~h}$ (dark) cycle with lights on at 06:00 a.m. The phase of females' estrous cycle was determined by vaginal lavage smears after one week of adaptation period. The smears were examined by light microscopy. Thereafter, female rats that were at the onset of estrous phase of the estrous cycle (Turner and Bagnara, 1976) were housed with sexually mature males overnight. There were always, one female and one male in a cage. The next morning females were smeared for the presence of sperm and returned to their previous home cages. This was counted as gestational day (GD) 1.

Dams were randomly assigned to MA-treated and saline-treated (controls). On GD 1 the daily injections started and continued till the day of delivery, which usually occurred on GD 22 (for details see Šlamberová et al., 2005). MA (Sigma-Aldrich ${ }^{\circledR}$ ) was injected subcutaneously (s.c.) in a dose of $5 \mathrm{mg} / \mathrm{kg}$, saline was injected s.c. at the same time in the same volume as MA.

The day of delivery was counted as postnatal day (PD) 0. On PD 21, pups were weaned and group-housed by sex. Animals were left undisturbed until adulthood. Always one male rat (PD 70-90) per group was used in each experiment from each litter to avoid litter effects. Females were used in other experiments that will be presented as a part of another study.

\section{Open field test - Laboras}

In total 64 adult male rats $(\mathrm{n}=8)$ were tested in Laboras apparatus (Metris B.V., Netherlands) for natural behavior. Laboras is a fully automatic system for continuous behavior recognition and tracking in small rodents. Single animal was placed to the plexiglass cage $(45 \times 30 \times 30 \mathrm{~cm})$ filled with bedding material, that was covered and equipped as normal home cage with food and water available ad libitum. The cage was placed on a triangular sensor platform $(95 \times 75 \times 75 \mathrm{~cm})$. The platform was connecting the basis of the system with a computer for continuous recording of different types of activities during the time of Open field testing. The movements' records afterwards were analyzed by Laboras software.

Challenge dose of the tested drugs [cocaine $(5 \mathrm{mg} / \mathrm{kg})$; morphine $(5 \mathrm{mg} / \mathrm{kg})$ ] or saline $(1 \mathrm{ml} / \mathrm{kg}$ ) was administered immediately prior to placing the animal to the Laboras cage to both of the prenatal groups (prenatally MA-exposed and prenatally saline-exposed). Each animal was tested separately. The behavior was monitored for 1 hour. The duration of each behavior was analyzed within six 10-minute intervals. Following parameters were analyzed in all animals during the 1-h period of testing: the duration of locomotion, rearing (exploratory behavior) and total distance travelled.

\section{Plantar test}

Other 32 animals $(n=8)$ were used to test nociception. Plantar test (Plantar test; Ugo Basile, Comerio, Italy) was used to measure pain threshold. A beam generator, which is controlled by the experimenter under the floor of the plexiglass box 
(size $27 \times 17 \times 14 \mathrm{~cm}$ ) allows to stimulate the sole (planta) of the paw in a freely moving rat. The latency of paw withdrawal from painful heat stimulus was measured for each of the four paws. Latency to withdrawal of the tail was measured as a modified method of the Tail-flick test. The maximal intensity was set to 90 and cut-off time was $22 \mathrm{~s}$ to prevent tissue damage.

Four measures were done in 15-minute intervals. First measure (time 0) was used as a control without drug challenge. When the first measure was finished, challenge dose of the tested drug [cocaine $(5 \mathrm{mg} / \mathrm{kg})$; morphine $(5 \mathrm{mg} / \mathrm{kg})$ ] was injected. Next measures were performed 15, 30, and 45 minutes after the drug administration. Thus, the effect of challenge dose of cocaine or morphine was compared during time period of 45 minutes in prenatally MA- and saline-exposed male rats.

Conditioned place preference (CPP)

Another 32 adult male rats $(\mathrm{n}=8)$ were used to test drug [cocaine $(5 \mathrm{mg} / \mathrm{kg})$; morphine $(5 \mathrm{mg} / \mathrm{kg})$ ] reward conditioning and how it is affected by prenatal drug exposure. The CPP apparatus dimensions and general procedures were modified from the work of Sanchez et al. (2003). The apparatus and the methodological procedure were in detail described in our previous study (Šlamberová et al., 2011b).

The place conditioning procedure consisted of three phases: pre-exposure, conditioning, and the CPP test as in work of Mueller and Stewart (2000). Pre-exposure: On the Day 1, animals received a single pre-exposure test in which they were placed in the center choice chamber with the doors open to allow access to the entire apparatus for $15 \mathrm{~min}$. The amount of time spent in each chamber was monitored and used to assess unconditioned preferences. Conditioning: During the following conditioning phase ( 8 days), rats were assigned to receive drug [cocaine $(5 \mathrm{mg} / \mathrm{kg})$; morphine $(5 \mathrm{mg} / \mathrm{kg})$ ] in one of the two chambers and saline in the second one. Half of each group started the experiment on the drug-paired side and half on the saline-paired side. After administration of drug (cocaine or morphine) or saline, animal was allowed to explore the specific chamber for 1 hour. The center chamber was never used during conditioning and was blocked by doors. CPP test: Two days after the last conditioning trial (Day 12), a test for CPP was given. Animals were placed in the center choice chamber with the doors opened and allowed free access to the entire apparatus for $15 \mathrm{~min}$. The time spent in each chamber and number of entries was recorded to assess individual preferences. No injections were given during the CPP test, maintaining the same procedure as that used during the pre-exposure test. Active drugseeking behavior was developed if the animal preferred the chamber that was associated with the drug injection. 


\section{Statistical analyses}

Data from each adult challenge (cocaine and morphine, respectively) were analyzed separately $(n=8)$.

Laboras. All behavioral activities were evaluated separately. Three-way ANOVA (between factors: prenatal drug, challenge drug; within factors: 10-minute intervals) was used.

Plantar test. Average of measurements of both forelimbs (left and right), both hind limbs and all tail measurements, respectively, were used for statistical analyses.

Two-way ANOVA (between factor: prenatal drug exposure; within factor:

15-minute intervals) was used.

CPP test. Three-way ANOVA (between factors: prenatal exposure, chamber with or without challenge drug; within factor: time - before vs. after conditioning) was used to analyze differences in number of entries to chambers and total time spent in the specific chamber.

Bonferroni post-hoc test was used when appropriate. Differences were considered significant if $\mathrm{p}<0.05$.

All statistical data in this report are presented as $[F(N-1, n-N)=x x . x x ; p<0.0 x]$, where $\mathrm{F}=$ test criterion of ANOVA, $\mathrm{N}-1$ = degrees of freedom of groups, $\mathrm{n}-\mathrm{N}=$ degrees of freedom of individual subjects, $\mathrm{p}=$ probability level.

\section{Results}

\section{Cocaine}

Open field test - Laboras

Four groups were tested in Laboras: prenatally saline- and MA-exposed rats treated with cocaine or saline in adulthood.

Locomotion (Figure 1A). Cocaine challenge dose $(5 \mathrm{mg} / \mathrm{kg})$ increased the time of locomotion in prenatally saline-exposed rats, while it did not change it in prenatally MA-exposed rats $[F(1,28)=6.59 ; p<0.05]$. In addition, prenatally MA-exposed rats without cocaine challenge displayed increased locomotion in the first 10-minute interval relative to prenatally saline-exposed rats without cocaine $[F(5,140)=4.12$; $P<0.01]$ or prenatally $M A$-exposed rats with cocaine challenge dose $[F(5,140)=5.05$; $\mathrm{P}<0.001]$.

Rearing (Figure 1B). Cocaine challenge dose $(5 \mathrm{mg} / \mathrm{kg}$ ) increased the time spent with rearing in prenatally saline-exposed rats, while did not change it in prenatally MA-exposed rats $[F(1,28)=6.59 ; p<0.05]$. In addition, prenatally MA-exposed rats with cocaine displayed decreased rearing activity relative to prenatally MA-exposed rats without cocaine in the first two 10 -minute intervals $[F(5,140)=3.67 ; p<0.01]$.

Distance (Figure 1C). Cocaine challenge dose $(5 \mathrm{mg} / \mathrm{kg})$ increased the total distance moved in prenatally saline-exposed rats, while did not change it in prenatally 
MA-exposed rats $[F(1,28)=5.90 ; p<0.05]$. In addition, prenatally MA-exposed rats without cocaine challenge displayed increased distance in the first 10-minute interval relative to prenatally saline-exposed rats without cocaine $[F(5,140)=3.83$; $\mathrm{p}<0.01]$ or prenatally $M A$-exposed rats with cocaine challenge dose $[F(5,140)=2.80$; $\mathrm{p}<0.05]$.

A

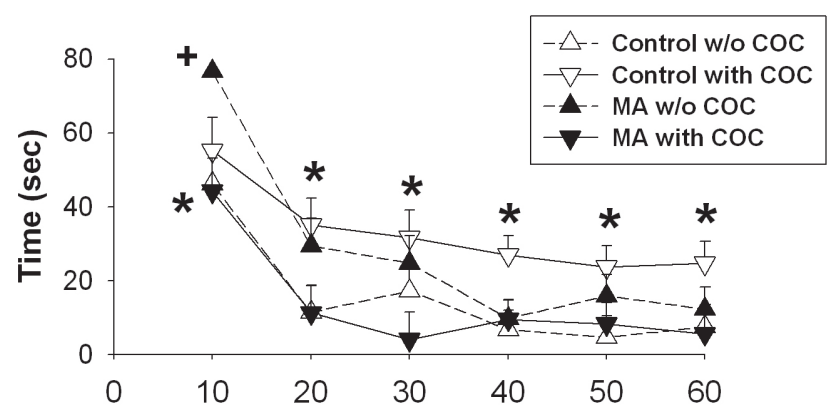

B

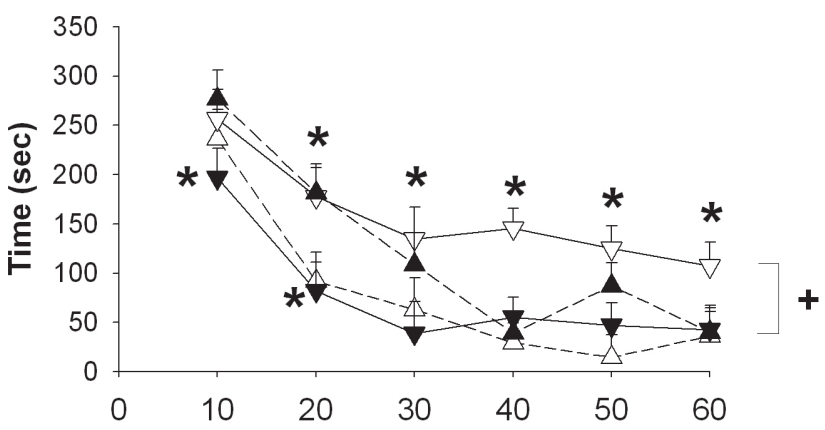

C

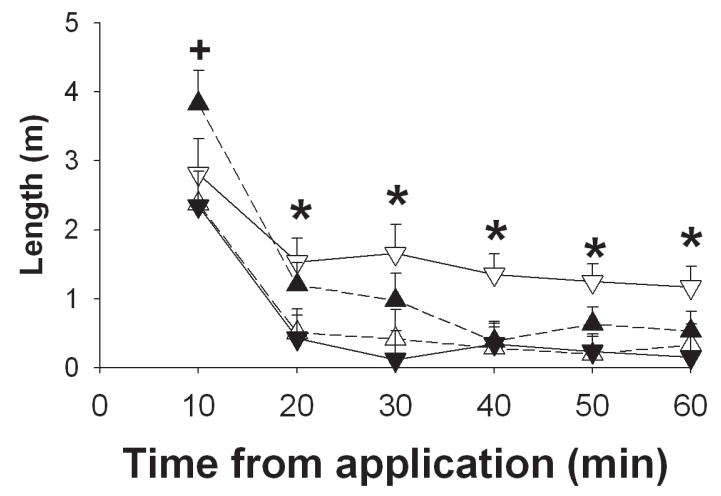

Figure 1 - The effect of prenatal MA exposure $(5 \mathrm{mg} / \mathrm{kg})$ and challenge dose of cocaine in adulthood $(5 \mathrm{mg} / \mathrm{kg})$ on locomotion (A), rearing (B) and distance $(C)$ in Laboras test. Values are means $\pm \operatorname{SEM}(n=8)$.

$*_{p}<0.05$ vs. animals regardless of prenatal exposure without cocaine treatment (effect of cocaine challenge dose) $+p<0.05$ vs. prenatally saline-exposed rats regardless of cocaine treatment (effect of prenatal MA exposure) 


\section{Plantar test}

All animals received one cocaine dose after first measurement in the time 0 to see possible analgesic effect of cocaine and how it differs based on the prenatal exposure. Time 0 was used as control measurement in the Plantar test. There was no difference induced by prenatal MA exposure and no analgesic effect induced by cocaine challenge dose $(5 \mathrm{mg} / \mathrm{kg}$ ) in forelimbs (Figure $2 \mathrm{~A}$ ) or hind limbs (Figure 2B). In the tail (Figure 2C) the cocaine challenge dose showed the analgesic effect in the $30^{\text {th }}$ and $45^{\text {th }}$ minute after cocaine administration $[F(3,42)=7.11 ; p<0.0001]$. This analgesic effect was independent of the prenatal drug exposure.

\section{A}

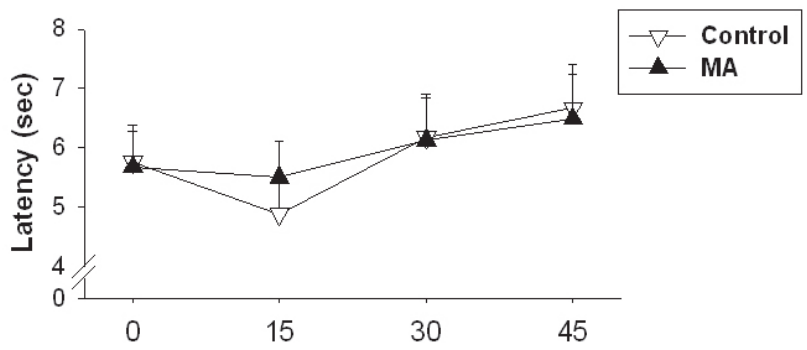

B

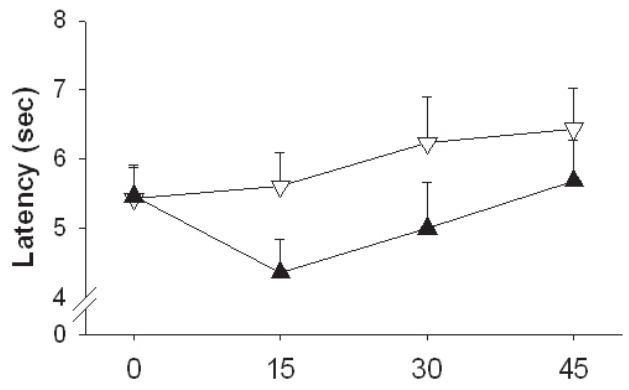

C

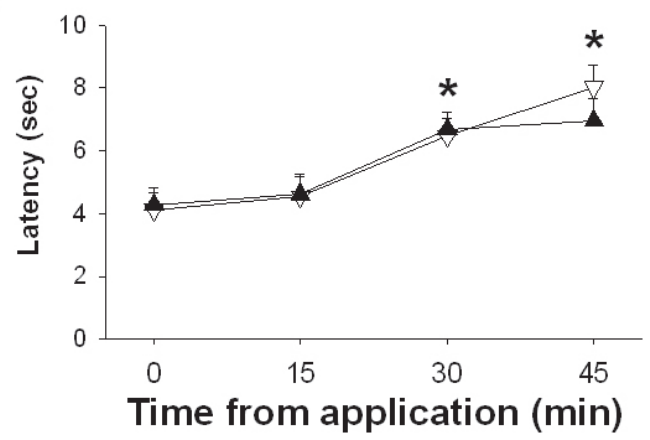

Figure 2 - The effect of prenatal MA exposure $(5 \mathrm{mg} / \mathrm{kg})$ and challenge dose of cocaine in adulthood $(5 \mathrm{mg} / \mathrm{kg}$ ) on nociception in the forelimbs (A), the hind limbs (B) and the tail (C) examined with Plantar test. Values are means \pm SEM $(n=8)$.

$*_{p}<0.05$ vs. first (control) measure (analgesic effect of cocaine) 
Conditioned place preference (CPP)

After cocaine conditioning, prenatally saline-exposed rats displayed higher number of entries $[F(1,42)=5.15 ; p<0.01]$ and increased total time spent in the chamber $[F(1,42)=3.80 ; p<0.05]$ associated with cocaine $(5 \mathrm{mg} / \mathrm{kg})$ in the CPP test than in the chamber associated with saline administration. This increase was not apparent in rats prenatally exposed to MA (Table 1).

Table 1 - Effect of the drug challenge dose on time spent in a chamber associated with the drug and number of entries to the chamber associated with the drug

\begin{tabular}{lcccc} 
& \multicolumn{3}{c}{ Time } & \multicolumn{2}{c}{ Entries } \\
\cline { 2 - 5 } & control & MA & control & MA \\
\hline Cocaine & $\uparrow$ & - & $\uparrow$ & - \\
$5 \mathrm{mg} / \mathrm{kg}$ & $\uparrow$ & $\uparrow$ & $\uparrow$ & $\uparrow$ \\
\hline $\begin{array}{l}\text { Morphine } \\
5 \mathrm{mg} / \mathrm{kg}\end{array}$ & $\uparrow$ & $\uparrow$ & $\uparrow$ & $\uparrow$ \\
\hline
\end{tabular}

Arrows show increased visits (entries) or time spent in the chamber associated with the drug. Dash means no difference in the number of visits (entries) or time spent in the chamber associated with the drug or chamber associated with saline

\section{Morphine}

Open field test - Laboras

Four groups were tested in Laboras: prenatally saline- and MA-exposed rats treated with morphine or saline in adulthood.

Locomotion (Figure 3A). Morphine challenge dose ( $5 \mathrm{mg} / \mathrm{kg}$ ) decreased the time of locomotion in prenatally MA-exposed rats, while did not change it in prenatally saline-exposed rats during the first 30 minutes of the Laboras test $[F(5,140)=4.80$; $\mathrm{p}<0.01$ ]. In addition, prenatally MA-exposed rats without morphine challenge spent more time by locomotion than prenatally saline-exposed rats without morphine in adulthood during the first 30 minutes of the Laboras test $[F(5,140)=4.37 ; p<0.001]$. This prenatal MA-induced difference was not apparent in the groups of animals, who received morphine challenge in adulthood.

Rearing (Figure 3B). Morphine challenge dose $(5 \mathrm{mg} / \mathrm{kg}$ ) decreased the time spent by rearing in both, prenatally saline-exposed and prenatally MA-exposed rats during the first 30 minutes of the Laboras test $[F(5,140)=8.38 ; p<0.0001]$. Prenatal MA exposure did not induce any difference between groups.

Distance (Figure 3C). Morphine challenge dose $(5 \mathrm{mg} / \mathrm{kg}$ ) decreased the total distance moved in prenatally MA-exposed rats, while did not change it in prenatally saline-exposed rats during the first 30 minutes of the Laboras test $[F(5,140)=3.72$; 
A

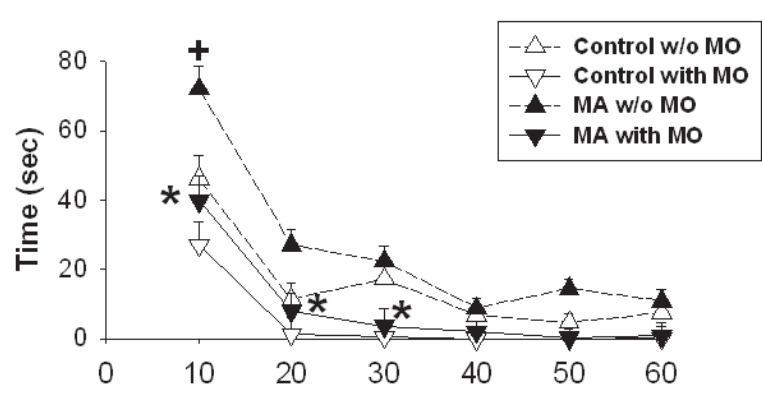

B

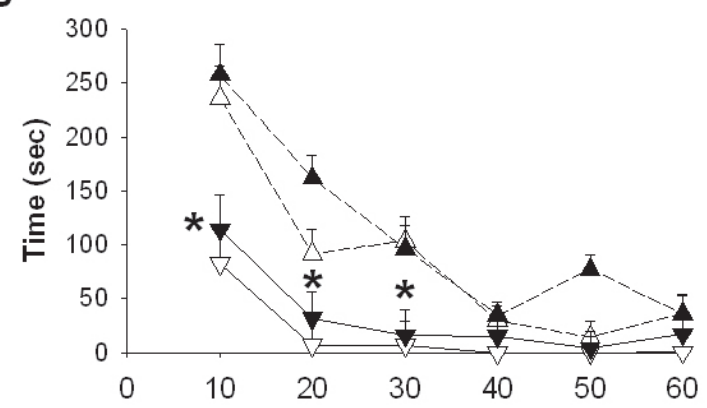

C

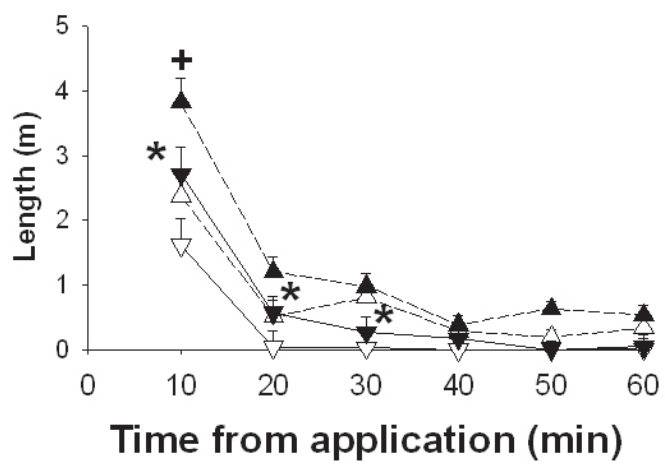

Figure 3 - The effect of prenatal MA exposure $(5 \mathrm{mg} / \mathrm{kg})$ and challenge dose of morphine in adulthood $(5 \mathrm{mg} / \mathrm{kg})$ on locomotion $(A)$, rearing $(B)$ and distance $(C)$ in Laboras test. Values are means \pm SEM $(n=8)$. ${ }^{*} p<0.05$ vs. animals regardless of prenatal exposure without morphine treatment (effect of morphine challenge dose)

$+p<0.05$ vs. prenatally saline-exposed rats regardless of morphine treatment (effect of prenatal MA exposure))

$\mathrm{p}<0.05]$. In addition, prenatally MA-exposed rats without morphine challenge walked longer distance than prenatally saline-exposed rats without morphine in adulthood during the first 10 minutes of the Laboras test $[F(5,140)=5.61$; $\mathrm{p}<0.0001]$. This prenatal MA-induced difference was not apparent in the groups of animals, who received morphine challenge in adulthood. 
Plantar test

All animals received one morphine dose after first measurement in the time 0 to see possible analgesic effect of morphine and how it differs based on the prenatal exposure. Time 0 was used as control measurement in the Plantar test. Forelimbs (Figure 4A). Morphine induced analgesic effect in forelimbs of prenatally saline-exposed rats that increases with the time $[F(3,42)=6.69 ; p<0.001]$. In prenatally MA-exposed rats was the analgesic effect of morphine postponed and started after 30 minutes from morphine administration. In addition, prenatal MA exposure induced decrease in the pain threshold $[F(1,14)=3.32 ; p<0.05]$.

Hind limbs (Figure 4B). Morphine induced analgesic effect in hind limbs of prenatally saline-exposed rats that increased with the time that however started 30 minutes after morphine administration $[F(3,42)=3.72 ; p<0.05]$. Morphine did not have an analgesic effect in prenatally MA-exposed rats. In addition, prenatal $M A$ exposure induced decrease in the pain threshold in hind limbs $[F(1,14)=3.34$; $\mathrm{p}<0.05]$.

Tail (Figure 4C). In the tail morphine induced fast growing analgesia in both, prenatally saline-exposed and prenatally $M A$-exposed rats $[F(3,42)=43.54$; $p<0.0001]$. This analgesic effect of morphine did not differ based on the prenatal drug exposure.

\section{Conditioned place preference (CPP)}

After morphine conditioning, both, prenatally saline-exposed and prenatally MA-exposed rats displayed higher number of entries $[F(1,42)=33.42 ; p<0.001]$ and increased total time spent in the chamber $[F(1,42)=50.39 ; p<0.0001]$ associated with morphine $(5 \mathrm{mg} / \mathrm{kg})$ in the CPP test than in the chamber associated with saline administration. This effect showing increased drug-seeking behavior did not differ in respect of the prenatal drug exposure (Table 1).

\section{Discussion}

Our data demonstrate differences in the effect of cocaine and morphine in all conducted tests. Cocaine increased the activity in the Laboras test in prenatally saline-exposed, but decreased it in prenatally MA-exposed rats. Cocaine had an analgesic effect only on the tail and this effect was independent of the prenatal drug exposure. Also, prenatal MA exposure induced rather tolerance to cocaine then sensitization in the CPP test. On the other hand, morphine decreased locomotion and distance traveled in prenatally MA-exposed rats and the rearing activity in both, the prenatally MA-exposed and prenatally saline-exposed rats in the Laboras. In the Plantar test the results demonstrate that morphine had an analgesic effect in prenatally saline-exposed rats, but this effect was lowered or suppressed in prenatally MA-exposed rats on forelimbs and hind limbs. In the CPP 


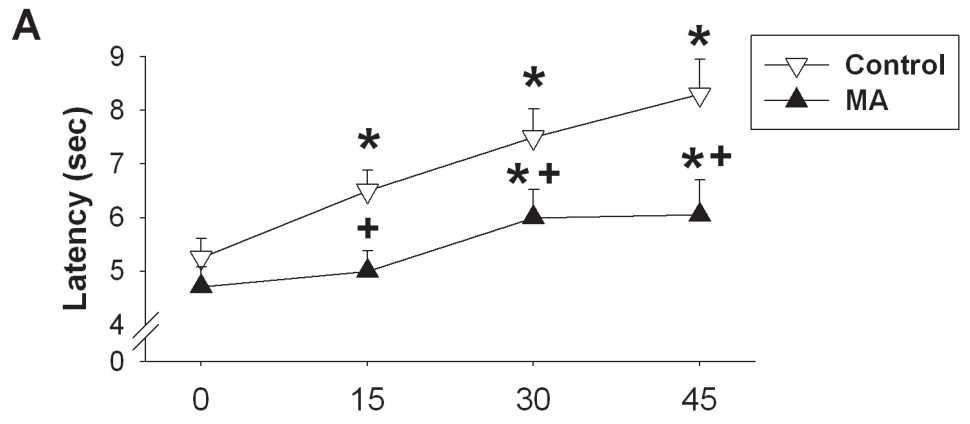

B

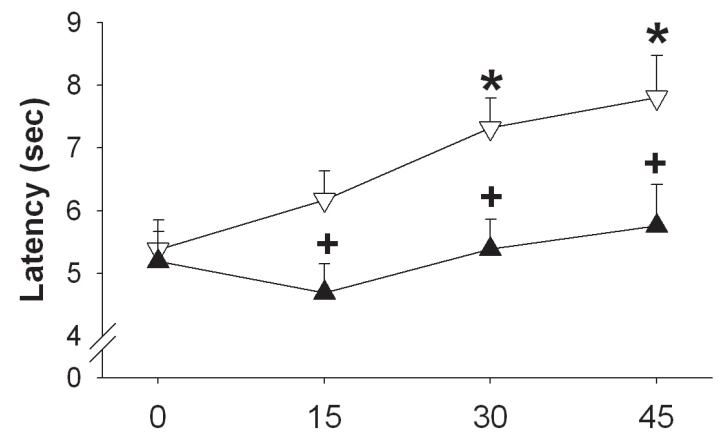

C

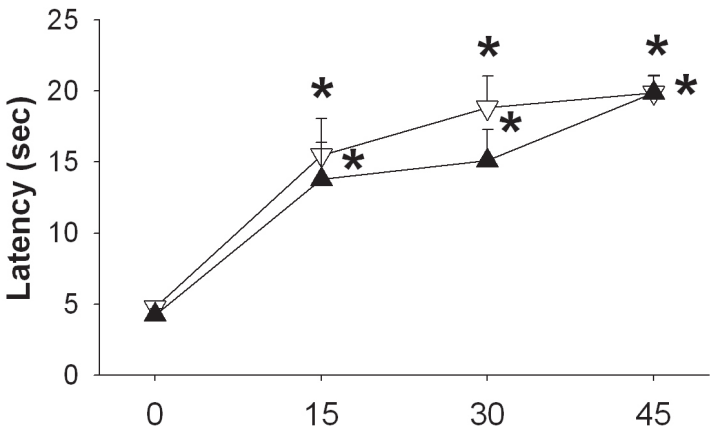

Time from application (min)

Figure 4 - The effect of prenatal MA exposure $(5 \mathrm{mg} / \mathrm{kg})$ and challenge dose of morphine in adulthood $(5 \mathrm{mg} / \mathrm{kg}$ ) on nociception in the forelimbs (A), the hind limbs (B) and the tail (C) examined with Plantar test. Values are means \pm SEM $(n=8)$

$* p<0.05$ vs. first (control) measure (analgesic effect of morphine)

$+p<0.05$ vs. prenatally saline-exposed rats (effect of prenatal MA exposure)

test morphine induced drug-seeking behavior, which however did not differ in respect to the prenatal drug exposure.

The behavioral data showing increased locomotion, rearing, as well as distance travelled by prenatally saline-exposed rats in the Laboras test are in agreement 
with many studies demonstrating increased locomotor activity in animals after administration of psychostimulants (Carey and Gui, 1997; Tzschentke and Schmidt, 1998; Carey and Damianopoulos, 2006; Ago et al., 2008). However, this increase was not apparent in animals prenatally exposed to MA in the present study. This is an interesting finding showing effect of prenatal MA exposure on possible development of tolerance to cocaine administration. Similar effect was shown by study of Peltier et al. (1996) as discussing below. In contrast to cocaine, our results show morphine-induced decrease in locomotion which did not differ based on the prenatal exposure and is in agreement with many studies of others (Vezina and Stewart, 1987; Nazarian et al., 1999; Patti et al., 2005).

The data showing changes in nociception are in agreement with many studies showing analgesic effect of both, morphine and cocaine. Morphine is well known analgesic drug often used in oncology (Vadalouca et al., 2008). Psychostimulants, including cocaine, were used as local as well as general anaesthetics for decades, even though they are not so often used for systemic application recently (Fleming et al., 1990; Young and MacKenzie, 1992). Our findings showing decreased analgesic effect on forelimbs and hind limbs but not the tail in prenatally MA-exposed relative to prenatally saline-exposed rats suggest long-term effect of prenatal MA exposure affecting especially supraspinal analgesic mechanisms (Zemlan et al., 1984; Roerig and Fujimoto, 1988). The anti-analgesic effect of prenatal MA exposure is supported by our previous studies (Šlamberová et al., 2011b; Yamamotová et al., 2011) as well as studies of others (Chen et al., 2010). Chen et al. suggested that prenatal MA exposure could predispose an alteration in the development of nociceptive neuronal network, which leads to a long-lasting status of hypersensitivity to pain stimulations in the offspring.

In contrast to our expectation, our data from the CPP test demonstrate no increase induced by prenatal MA exposure in the active drug-seeking behavior. In contrast to our findings, studies of drug abuse in prenatally cocaine-exposed adult rats (Heyser et al., 1992; Rocha et al., 2002; Estelles et al., 2006) showed increased predisposition to drug abuse in self-administration and CPP tests. These inconsistencies of findings with our model of prenatal MA exposure suggest that cocaine is more potent drug for causing long-term addiction than MA. Even more, we demonstrate rather decreased preference of the cocaine-associated chamber in prenatally MA-exposed rats which would in other words suggest tolerance to cocaine conditioning in prenatally MA-exposed rats.

To the best of our knowledge, there is only one study supporting our finding demonstrating tolerance to cocaine induced by MA. Peltier et al. (1996) demonstrated that chronic treatment with psychostimulants, such as amphetamine and MA, produces cross-tolerance to both the discriminative and reinforcing effects of cocaine. Study of Gygi et al. (1996) suggesting that MA causes tolerance to serotonergic effects of psychostimulants might also support our results. It was repeatedly shown that MA and amphetamine affect the noradrenergic system of 
the CNS the most, the dopaminergic system less, and at minimum the serotonergic system. On the other hand, cocaine seems to affect the serotonergic system the most (Fleckenstein et al., 2000; Rothman et al., 2001; Shoblock et al., 2003). This might be an explanation for our results.

With respect to the effect of morphine in the CPP, our present data demonstrated increased drug seeking behavior that however did not differ based on the prenatal drug exposure. As mentioned above, there are studies available (Heyser et al., 1992; Rocha et al., 2002; Estelles et al., 2006) showing increased drug-seeking behavior of cocaine or morphine in animals prenatally exposed to cocaine, which is in disagreement to our results. On the other hand, prenatal morphine exposure was shown not to affect self-administration of morphine or cocaine in adulthood (Riley and Vathy, 2006; Vathy et al., 2007). In addition, study of Vela et al. (1998) demonstrated sex differences of cross-effect between prenatal cannabinoids exposure and morphine self-administration in adulthood. Specifically, adult female rats born from mothers that were daily treated with delta9tetrahydrocannabinol (THC) during gestation and lactation periods, exhibited a statistically significant increase in the rate of acquisition of intravenous morphine self-administration behavior when compared with females born from vehicleexposed mothers, an effect that did not exist in THC-exposed male offspring. Thus, it seems that the possibility of increased drug-seeking of drugs in adulthood depends on the drug that was the animal exposed prenatally and also on the sex. Therefore, our future studies are planned to examine the cross-effects between prenatal MA exposure and sensitivity to the drugs in adult females.

In conclusion, our data demonstrate that there is a cross-effect between prenatal MA exposure and the challenge dose of other drug in adulthood, however drug-seeking behavior is not increased by prenatal MA exposure as we expected.

\section{References}

Ago, Y., Arikawa, S., Yata, M., Yano, K., Abe, M., Takuma, K., Matsuda, T. (2008) Antidepressant-like effects of the glucocorticoid receptor antagonist RU-43044 are associated with changes in prefrontal dopamine in mouse models of depression. Neuropharmacology 55, 1355-1363.

Arnold, J. C. (2005) The role of endocannabinoid transmission in cocaine addiction. Pharmacol. Biochem. Behav. 81, 396-406.

Bartoletti, M., Gaiardi, M., Gubellini, C., Bacchi, A., Babbini, M. (1985) Cross-sensitization to the excitatory effect of morphine in post-dependent rats. Neuropharmacology 24, 889-893.

Bernášková, K., Matějovská, I., Šlamberová, R. (2011) Postnatal challenge dose of methamphetamine amplifies anticonvulsant effects of prenatal methamphetamine exposure on epileptiform activity induced by electrical stimulation in adult male rats. Exp. Neurol. 229, 282-287.

Bonate, P. L., Swann, A., Silverman, P. B. (1997) Behavioral sensitization to cocaine in the absence of altered brain cocaine levels. Pharmacol. Biochem. Behav. 57, 665-669.

Bubeníková-Valešová,V., Kačer, P., Syslová, K., Rambousek, L., Janovský, M., Schutová, B., Hrubá, L., Šlamberová, R. (2009) Prenatal methamphetamine exposure affects the mesolimbic dopaminergic system and behavior in adult offspring. Int. J. Dev. Neurosci. 27, 525-530.

Šlamberová R. et al. 
Carey, R., Gui, J. (1997) A simple and reliable method for the positive identification of pavlovian conditioned cocaine effects in open-field behavior. J. Neurosci. Methods 73, 1-8.

Carey, R. J., Damianopoulos, E. N. (2006) Cocaine conditioning and sensitization: the habituation factor. Pharmacol. Biochem. Behav. 84, 128-133.

Chen, J.Y., Yeh, G. C., Tao, P. L., Kuo, C. T., Chen, K. B., Wen, Y. R. (2010) Prenatal exposure to methamphetamine alters the mechanical withdrawal threshold and tonic hyperalgesia in the offspring. Neurotoxicology $\mathbf{3 1}$, $432-438$.

Estelles, J., Rodriguez-Arias, M., Maldonado, C., Aguilar, M. A., Minarro, J. (2006) Gestational exposure to cocaine alters cocaine reward. Behav. Pharmacol. 17, 509-515.

Fattore, L., Deiana, S., Spano, S. M., Cossu, G., Fadda, P., Scherma, M., Fratta, W. (2005) Endocannabinoid system and opioid addiction: behavioural aspects. Pharmacol. Biochem. Behav. 81, 343-359.

Ferrario, C. R., Robinson, T. E. (2007) Amphetamine pretreatment accelerates the subsequent escalation of cocaine self-administration behavior. Eur. Neuropsychopharmacol. 17, 352-357.

Fleckenstein, A. E., Gibb, J.W., Hanson, G. R. (2000) Differential effects of stimulants on monoaminergic transporters: pharmacological consequences and implications for neurotoxicity. Eur.J. Pharmacol. 406, 1-13.

Fleming, J.A., Byck, R., Barash, P. G. (1990) Pharmacology and therapeutic applications of cocaine. Anesthesiology 73, 518-531.

Gagin, R., Kook, N., Cohen, E., Shavit, Y. (1997) Prenatal morphine enhances morphine-conditioned place preference in adult rats. Pharmacol. Biochem. Behav. 58, 525-528.

Gygi, M. P., Gygi, S. P., Johnson, M., Wilkins, D. G., Gibb, J.W., Hanson, G. R. (1996) Mechanisms for tolerance to methamphetamine effects. Neuropharmacology 35, 751-757.

He, S., Grasing, K. (2004) Chronic opiate treatment enhances both cocaine-reinforced and cocaine-seeking behaviors following opiate withdrawal. Drug Alcohol Depend. 75, 215-221.

Heyser, C. J., Goodwin, G. A., Moody, C.A., Spear, L. P. (1992) Prenatal cocaine exposure attenuates cocaineinduced odor preference in infant rats. Pharmacol. Biochem. Behav. 42, 169-173.

Horger, B. A., Giles, M. K., Schenk, S. (1992) Preexposure to amphetamine and nicotine predisposes rats to self-administer a low dose of cocaine. Psychopharmacology (Berl.) 107, 271-276.

Leri, F., Flores, J., Rajabi, H., Stewart, J. (2003) Effects of cocaine in rats exposed to heroin. Neuropsychopharmacology 28, 2102-2116.

Malanga, C. J., Kosofsky, B. E. (2003) Does drug abuse beget drug abuse? Behavioral analysis of addiction liability in animal models of prenatal drug exposure. Brain Res. Dev. Brain Res. 147, 47-57.

Marwick, C. (2000) NIDA seeking data on effect of fetal exposure to methamphetamine. JAMA 283, 2225-2226.

Mueller, D., Stewart, J. (2000) Cocaine-induced conditioned place preference: reinstatement by priming injections of cocaine after extinction. Behav. Brain Res. 115, 39-47.

Nazarian, A., Rodarte-Freeman, A. L., McDougall, S. A. (1999) Dopaminergic modulation of kappa opioidmediated ultrasonic vocalization, antinociception, and locomotor activity in the preweanling rat. Behav. Neurosci. 113, 816-825.

Patti, C. L., Frussa-Filho, R., Silva, R. H., Carvalho, R. C., Kameda, S. R., Takatsu-Coleman, A. L., Cunha, J. L., Abilio, V. C. (2005) Behavioral characterization of morphine effects on motor activity in mice. Pharmacol. Biochem. Behav. 81, 923-927.

Peltier, R. L., Li, D. H., Lytle, D., Taylor, C. M., Emmett-Oglesby, M.W. (1996) Chronic d-amphetamine or methamphetamine produces cross-tolerance to the discriminative and reinforcing stimulus effects of cocaine. J. Pharmacol. Exp. Ther. 277, 212-218.

Riley, M. A., Vathy, I. (2006) Mid- to late gestational morphine exposure does not alter the rewarding properties of morphine in adult male rats. Neuropharmacology 51, 295-304. 
Rocha, B. A., Mead, A. N., Kosofsky, B. E. (2002) Increased vulnerability to self-administer cocaine in mice prenatally exposed to cocaine. Psychopharmacology (Berl.) 163, 221-229.

Roerig, S. C., Fujimoto, J. M. (1988) Morphine antinociception in different strains of mice: relationship of supraspinal-spinal multiplicative interaction to tolerance. J. Pharmacol. Exp. Ther. 247, 603-608.

Rothman, R. B., Baumann, M. H., Dersch, C. M., Romero, D.V., Rice, K. C., Carroll, F. I., Partilla, J. S. (2001) Amphetamine-type central nervous system stimulants release norepinephrine more potently than they release dopamine and serotonin. Synapse 39, 32-41.

Sanchez, C. J., Bailie, T. M., Wu, W. R., Li, N., Sorg, B. A. (2003) Manipulation of dopamine d1-like receptor activation in the rat medial prefrontal cortex alters stress- and cocaine-induced reinstatement of conditioned place preference behavior. Neuroscience 119, 497-505.

Schutová, B., Hrubá, L., Pometlová, M., Deykun, K., Šlamberová, R. (2008) Impact of methamphetamine administered prenatally and in adulthood on cognitive functions of male rats tested in Morris water maze. Prague Med. Rep. 109, 62-70.

Schutová, B., Hrubá, L., Pometlová, M., Šlamberová, R. (2009) Impact of prenatal and acute methamphetamine exposure on behaviour of adult male rats. Prague Med. Rep. 110, 67-78.

Shoblock, J. R., Sullivan, E. B., Maisonneuve, I. M., Glick, S. D. (2003) Neurochemical and behavioral differences between d-methamphetamine and d-amphetamine in rats. Psychopharmacology (Berl.) 165, 359-369.

Shuster, L., Yu, G., Bates, A. (1977) Sensitization to cocaine stimulation in mice. Psychopharmacology (Berl.) 52. 185-190.

Šlamberová, R., Charousová, P., Pometlová, M. (2005) Methamphetamine administration during gestation impairs maternal behavior. Dev. Psychobiol. 46, 57-65.

Šlamberová, R., Pometlová, M., Charousová, P. (2006) Postnatal development of rat pups is altered by prenatal methamphetamine exposure. Prog. Neuropsychopharmacol. Biol. Psychiatry 30, 82-88.

Šlamberová, R., Schutová, B., Matějovská, I., Bernášková, K., Rokyta, R. (2009) Effects of a single postnatal methamphetamine administration on NMDA-induced seizures are sex- and prenatal exposure-specific. Naunyn Schmiedebergs Arch. Pharmacol. 380, 109-114.

Šlamberová, R., Schutová, B., Hrubá, L., Pometlová, M. (2011a) Does prenatal methamphetamine exposure affect the drug-seeking behavior of adult male rats? Behav. Brain Res. 224, 50-86.

Šlamberová, R., Yamamotová, A., Schutová, B., Hrubá, L., Pometlová, M. (2011b) Impact of prenatal methamphetamine exposure on the sensitivity to the same drug in adult male rats. Prague Med. Rep. 112, 102-114.

Suto, N., Austin, J. D., Tanabe, L. M., Kramer, M. K., Wright, D. A., Vezina, P. (2002) Previous exposure to VTA amphetamine enhances cocaine self-administration under a progressive ratio schedule in a D1 dopamine receptor dependent manner. Neuropsychopharmacology 27, 970-979.

Turner, C. D., Bagnara, J. T. (1976) Endocrinology of the ovary. In: General Endocrinology, eds. Turner, C. D., Bagnara, J. T., pp. 450-495,W. B. Saunders Company, Philadelphia.

Tzschentke, T. M. (1998) Measuring reward with the conditioned place preference paradigm: a comprehensive review of drug effects, recent progress and new issues. Prog. Neurobiol. 56, 613-672.

Tzschentke, T. M., Schmidt, W. J. (1998) The development of cocaine-induced behavioral sensitization is affected by discrete quinolinic acid lesions of the prelimbic medial prefrontal cortex. Brain Res. 795, 71-76.

Vadalouca, A., Moka, E., Argyra, E., Sikioti, P., Siafaka, I. (2008) Opioid rotation in patients with cancer: a review of the current literature. J. Opioid Manag. 4, 213-250.

Valvassori, S. S., Frey, B. N., Martins, M. R., Reus, G. Z., Schimidtz, F., Inacio, C. G., Kapczinski, F., Quevedo, J. (2007) Sensitization and cross-sensitization after chronic treatment with methylphenidate in adolescent Wistar rats. Behav. Pharmacol. 18, 205-212.

Šlamberová R. et al. 
Vathy, I., Šlamberová, R., Liu, X. (2007) Foster mother care but not prenatal morphine exposure enhances cocaine self-administration in young adult male and female rats. Dev. Psychobiol. 49, 463-473.

Vavřínková, B., Binder, T., Živný, J. (2001) Characteristics of a population of drug dependent pregnant women in the Czech Republic. Ceska Gynekol. 66, 285-291. (in Czech)

Vela, G., Martin, S., Garcia-Gil, L., Crespo, J.A., Ruiz-Gayo, M., Javier Fernandez-Ruiz, J., Garcia-Lecumberri, C., Pelaprat, D., Fuentes, J.A., Ramos, J.A., Ambrosio, E. (1998) Maternal exposure to delta9-

tetrahydrocannabinol facilitates morphine self-administration behavior and changes regional binding to central mu opioid receptors in adult offspring female rats. Brain Res. 807, 101-109.

Vezina, P., Stewart, J. (1987) Morphine conditioned place preference and locomotion: the effect of confinement during training. Psychopharmacology (Berl.) 93, 257-260.

Yamamotová, A., Hrubá, L., Schutová, B., Rokyta, R., Šlamberová, R. (2011) Perinatal effect of methamphetamine on nociception in adult Wistar rats. Int. J. Dev. Neurosci. 29, 85-92.

Young, E. R., MacKenzie, T.A. (1992) The pharmacology of local anesthetics - a review of the literature. J. Can. Dent. Assoc. 58, 34-42.

Zemlan, F. P., Kow, L. M., Pfaff, D.W. (1984) Analgesia after lesions of nucleus reticularis magnocellularis: differential effect on supraspinal versus spinal pain reflexes. Pain 18, 221-237. 